\title{
Research on Business English Teaching in Higher Vocational Education Based on CBI
}

\author{
Tong Youping \\ Jiangxi Modern Polytechnic College, Nanchang, Jiangxi, China
}

Keywords: CBI; business English; higher vocational English teaching; small class teaching mode

\begin{abstract}
Higher vocational education has always been the focus of our country. CBI is the teaching mode widely used in domestic subject education. The teaching mode is perfect and extended for the learning content, and is helpful to form the task and extracurricular information.CBI-based business English teaching model can break through the traditional English teaching model, and form the topic-based, task-based form and the various aspects of English effective integration, thus achieving classroom interaction. CBI can make the English classroom form the theme classroom to stimulate students' interest in learning. Therefore, it is of great significance for the achievement of English teaching goals and the improvement of students' English level.
\end{abstract}

\section{Introduction}

CBI teaching philosophy began the "immersion" experimental class in the 1960s. The teaching idea lies in the teaching of language based on a subject or based on a subject of teaching, and it isa second language teaching modelfully integrated with linguistics and cognitive theory based on the subject content or academic content and language teaching activities[1].CBI has changed the practice of separating language skills from the cultivation of language skills and the study of subject content in traditional language teaching. It advocates the use of language as the source of learning content, the content is set as the source of learning language, and thus, the learners acquire the language skills through learning content. With the rapid growth of the global economy and the increase in economic and trade activities, business English learning issued more and more widely. Undoubtedly, English has become a tool for understanding and communication.According to Brieger's division of business English, business English should contain three sections: language knowledge, communication skills and expertise.

The theme concept based on CBI reform the vocational English teaching, and give full consideration to the cultivation of vocational students in the practical application of spoken English ability, and thus to select the appropriate teaching content and teaching strategies in business English teaching of higher vocational students.To explore the small class of teaching model in the professional development of teachers is also of great importance. The professional development of teachers under the background refers to the improvement of teachers' knowledge, skills and attitudes in small class teaching. The play of small class teaching depends on the improvement of teachers 'quality, and the key to the improvement of teachers' quality lies in the professional development of teachers. The basic purpose of the professional development of small class teaching teachers is to promote the individualized learning of students. The diversified form of development. In this study, we focus on classroom teaching reform and focus on the role of teachers in the innovation model.

\section{The related theory and status}

\section{CBI basic knowledge}

CBI is a teaching method that is based on the subject or subject content to achieve the purpose of language learning. The teaching method advocates the complete integration of language learning and subject knowledge learning, and the "content" is as the basis.This method focus on the 
teachingchanging from the teaching language itself to learn through the subject of knowledge to obtain the target language of the language skills[2]. CBI is a language and content of the organic integration of foreign language teaching model[3].The theoretical basis of the content-based pedagogy is mainly cognitive science and second language acquisition theory. According to the cognitive science point of view, all human intelligence activities require both process and content knowledge [4]. Therefore, language learning requires listening, reading, other processes and content of the common role of knowledge. Only in this way can the learner's cognitive ability be raised to a higher level. According to Krashen's second language acquisition theory [5], language acquisition relies on "meaningful input".Therefore, second language acquisition should focus on meaning. The content-based CBI effectively combines the formal function and meaning of language, shifting the focus of teaching from the learning language itself to learning the language by learning the subject knowledge. This teaching method is conducive to stimulating students of learning interest and motivation to enable students to use the target language and to learn and absorb new knowledge. At the same time, the listening, speaking, reading, writing and other language skills are naturally improved [6]. According to the difference between language and subject knowledge in teaching, Brinton proposes that CBI can have three basic patterns: the theme-based language instruction, the sheltered subject content instruction, and the adjunct instruction. The theme-based language instruction will choose topics that are closely related to students' interests and interests, and use these topics as the carrier to train students to develop language skills. The main goal is language teaching. The theme-based language teaching mode is suitable for all kinds of phrases or foreign language level students. The sheltered subject content instruction is focused on subject knowledge teaching rather than language teaching. Students acquire natural language skills by mastering the subject knowledge. This model requires teachers to become familiar with both the subject knowledge and the target language, the students' second language or foreign language level must be in the middle or above.The the adjunct instructionaccounts for half of the subject knowledge teaching and language teaching. The subject knowledge teaching and language teaching are carried out by the subject teachers and the language teachers respectively. This mode requires the language teachers to cooperate closely, the students' second language or foreign language level must in the middle or above the senior [7].

\section{The status of business English teaching in higher vocational education}

With the rapid development of modern science and technology and economy in the world, business English has become a popular in the 1980s. After 40 years, with the increase in international trade and the popularity of English, business English teaching has also been rapid developed. However, in recent years, business English teaching problems are gradually emerging.

First, teacher can not fully mobilize the students in the teaching of learning. Business English involves a wide range of professional vocabulary and knowledge, such as trade, finance, accounting, insurance, law, transportation and management. These broad areas of knowledge can not simply rely on the teacher in the classroom teaching, moreover, the important thing is that the student is active in learning. In business English teaching, teachers are considered as the center, and more interesting, the task of students is to listen to lectures and notes, and then students complete the teacher's homework on time, to achieve the purpose of improving test scores. Students in the classroom has always been silent, and even do not want to participate in the practice and discussion of the classroom, which will inevitably affect the student's learning effect.

Second, there are teaching inefficiencies in classroom teaching. In recent years, the number of college enrollment increased year by year, the number of each class is also increasing.Table 1 shows nearly five years of business English professional enrollment of our school, and the number of English classes are more than 50 people, which give business English teaching a great deal of trouble. The learning level and learning interest ofstudentsis very different, resulting insignificant differences in the enthusiasmof students to participate in classroom activities. The teacher's assignment in teaching is difficult for some students, however, it is too easy for some students. The content of business English teaching is only applicable to some students which makes it difficult to meet the 
needs of students to achieve effective learning. In addition, students are expected to receive the most effective training in the shortest possible time and to be proficient in English in business situations.

Table 1Enrollment of business English in 2009 to 2016

\begin{tabular}{|c|c|c|c|c|c|}
\hline Year & 2012 & 2013 & 2014 & 2015 & 2016 \\
\hline Number & 50 & 52 & 54 & 58 & 63 \\
\hline
\end{tabular}

Third, in business English teaching, teachers have limitations. In the major colleges and universities engaged in business English teaching teachers in the majority of teachers even have no business English background. The teaching methods they use in teaching also remain in the teaching mode of ordinary English. There are still few teachers who can use English to teach business English or other professional courses. They are far from being able to meet the increasingly competitive market demand. For teachers, engaging in business English teaching is a challenge, which not only requires them to have a solid foundation of English, but also requires teachers have practical learning knowledge and abilityin international trade, international finance and international engineering.

Based on some literature investigation, basic practice situation of business English has been investigated and the results are listed in table 2.There is a lack of environment that students' communicative competence. In business English teaching, students' language skills and intercultural communication skills are needed to ensure that students can use English as a tool for cross-cultural communication after graduation. Therefore, this requires the teacher adopt appropriate cross-cultural communication in the daily teaching,and gradually cultivate students to accept the cultural sensitivity and cultural adaptability. Besides, in the classroom, teachers should encourage students to actively contact the Western culture outside the classroom. Students can use newspapers, magazines, media and network to understand the Western culture and it's better to contrast between Chinese and Western culture to form the two cultural awareness of the ultimate and accurate cross-cultural exchanges.

Table 2Analysis of practice situation of business English teaching of this school

\begin{tabular}{|c|c|c|c|}
\hline Practice Place & In Classroom & In School & Outside School \\
\hline Percentage(\%) & $60 \%$ & $23 \%$ & $27 \%$ \\
\hline Practice Program & Imports and Exports & Foreign Trade & BEC exams \\
\hline Percentage(\%) & $30 \%$ & $14 \%$ & $56 \%$ \\
\hline
\end{tabular}

\section{The feasibility of CBI in business English teaching}

On the one hand, the carrier ofthe CBI teaching model is vocational students. The vocational college students have their own judgment, observation and active learning ability, so, a profound understanding of their own development goals must meet the needs of social development. Therefore, the motivation of such students is not from the teacher unilaterally indoctrination and requirements, but entirely from their own needs for a particular knowledge. We can see that vocational colleges in the professional English teaching curriculum must meet students of the actual situation and the needs of the community.Commercial English professional students, as its carrier, is the implementation of CBI system. In addition, this carrier's professional also achieve the greatest benefit of learning through the CBI model.

On the other hand, the professional English major of vocational colleges is generally "cultivate English\&business compound talents", its main function is to provide language services and to help the two sides of the transaction decision-makers to communicate effectively. CBI teaching model advocates the integration of English language knowledge and professional knowledge to design teaching methods, fully embodies the purpose of English as a language tool, in essence, is fully in line with the objectives of higher vocational education personnel training. Then, the teacher is the implementer of the CBI teaching model. Teaching environment and teachers are the most important factors in teaching activities. It is necessary to implement the multimedia classroom teaching and 
construct a new teaching mode which can improve the students 'English language ability and autonomous learning ability, and the diversified construction of the teachers' team is also needed to introduce and popularize the CBI theme model to the vocational college English teaching in our country. The successful implementation of the CBI teaching model provides the possibility.

\section{The research design and results}

\section{Situation investigation and research design}

The theme concept based on CBI reform the vocational English teaching, and give full consideration to the cultivation of vocational students in the practical application of spoken English ability.

.The study selected the appropriate teaching content and teaching strategies, including the following three aspects. First, the small class teaching is performed. For this project, the 2016 new class is randomly selected as experimental class which is implemented of small classes of teaching; and another class is still the implementation of ordinary large classes, and class hours maintain unity. In the small class of teaching, teachers should allow each student to be equidistant teaching. Moreover,full enjoyment of educational resources are realized for small class students, and all-round to enhance students' ability to use oral English.

Second, small class teaching is with the theme of content-based teaching method. In the small class teaching, teachers combined with the CBI theme model, the current popular topic is selected, and business English communication is closely related to the various topics as the classroom teaching materials and topics.In addition, effective use of network resources, multimedia technology and other informative means should be adopted, so that students can access to authentic English dialogue, daily expression, European and American culture and related business knowledge.Based on the particular teaching content, itcan stimulate students to learn English, to guide their own learning, and to realize self-exploration.For students, a positive classroom environmentis created, and teachers are strive to explore students' innovative thinking and the ability, and further to guide students to actively and boldly participate in classroom discussions, reporting, presentation and other teaching activities to enhance the practice of classroom practice. Table 3 shows the difference of the two class teaching contents.

Table 3Different teaching contents comparison of two different classes

\begin{tabular}{|c|c|c|}
\hline Class & Teaching Content & Class Hour \\
\hline \multirow{3}{*}{$\begin{array}{c}\text { Experimental } \\
\text { Class }\end{array}$} & American Literary History & 8 \\
\cline { 2 - 3 } & Business Oral English in real business trading & 24 \\
\cline { 2 - 3 } & Practice in a foreign trading company & 32 \\
\hline \multirow{3}{*}{ Normal Class } & Skill of BEC exams & 8 \\
\cline { 2 - 3 } & Business Oral English in class & 32 \\
\cline { 2 - 3 } & Business written English & 24 \\
\hline
\end{tabular}

The third is changing the course evaluation method, not only to the end of the skills test results, but should pay attention to students on business English spoken language in the practical application of the embodiment, such as the growth of portfolio, student reporting, and innovative operations.

\section{Results of the research}

After a semester, the level test iscarried out and the results are shown in figure 1 . The implementation of small class teaching students in business speaking, listening ability is significantly stronger than the normal class students. In addition, the practice of small class teaching allows students to have a more real business English communication and writing environment, able to exercise studentsfrom a variety of aspects. 


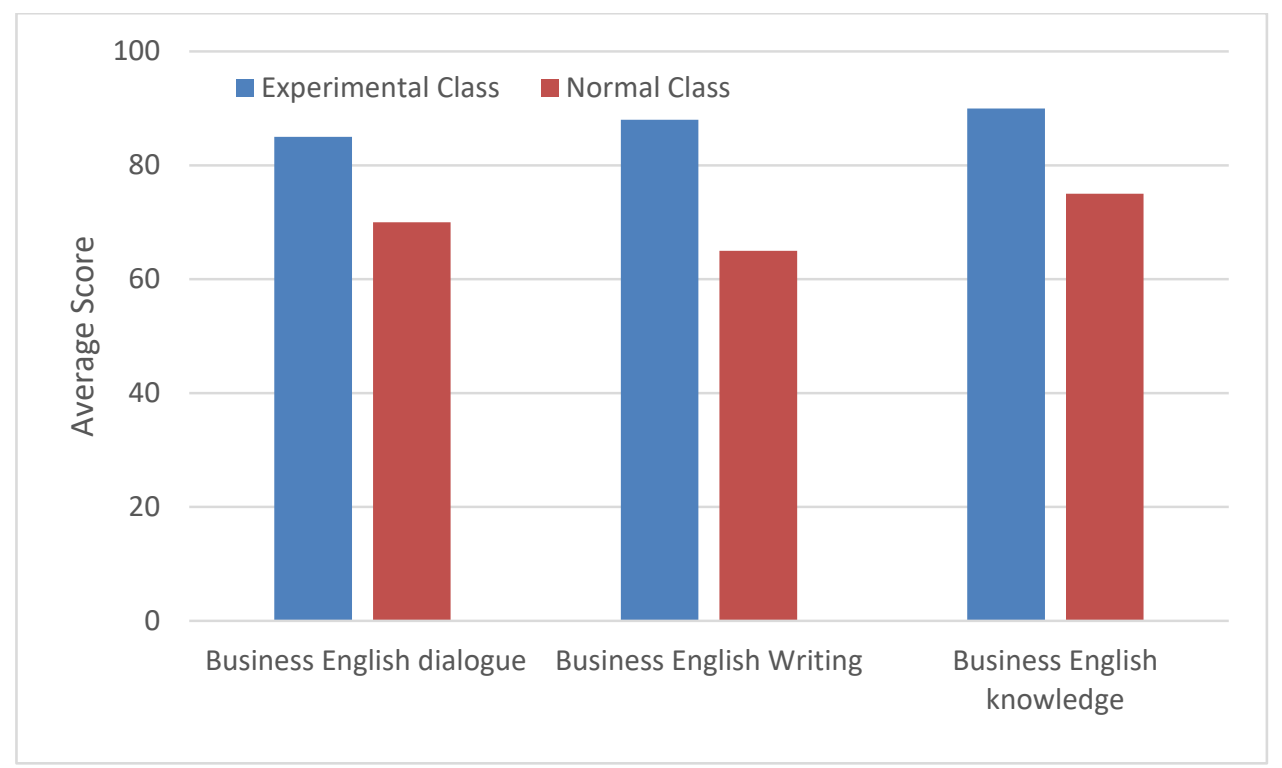

Figure 1 The average score of tests.

\section{Summary}

The creation of the small class teaching mode and the use of the CBI model contribute to the creation of a rich classroom context, which greatly stimulates students interest and motivation in learning English. It is a more natural way to develop students' English ability and it is helpful to attract students' attention. Besides, in this teaching mode, and teachers and students can effectively use multimedia and network technology. Students can access to authentic English materials, and then consider it as a powerful tool for exploring knowledge. By all this creative teaching mode, we can ultimately improve English communication of the vocational students. This model is as a new and advanced teaching mode for our country's higher vocational English reform and provides a new way in classroom business English teaching.

\section{References}

[1] Wang W. Adaptive "Content” in CBI for Business English Teaching in Chinese Universities Based on Needs Analysis[J]. Journal of Beijing University of Chemical Technology, 2014.

[2] Leaver,S.\&B.L.Stryker (ed.)Content -based Instruction in Foreign Language Education: Models and Methods [M].Washington,D.C.:Georgetown University Press,1997.

[3] Li L, Wei W. Research on University English Teaching Based on CBI[C]// International Conference on Economy, Management and Education Technology. 2016.

[4] Li L. A Study on Effects of Applying CBI to Business English Teaching[J]. Journal of Beijing International Studies University, 2010.

[5] Krashen,S.Principles \& Practice in Second LanguageAcquisition [M].Pergamon Press,1982.

[6] Kang M. Feasibility Research on Multimedia English Teaching in Higher Professional Education[J]. Sci/tech Information Development \& Economy, 2003.

[7] Brinton,D.M. M.A. Snow, \& M.B.Wesche,Content-based Second Language Instruction[M].University ofMichigan Press, 2003. 